\title{
Density Currents in the Chicago River: Characterization, Effects on Water Quality, and Potential Sources
}

\author{
P. Ryan Jackson ${ }^{\dagger}$ \\ Applied Ocean Physics and Engineering Department \\ Woods Hole Oceanographic Institution \\ Woods Hole, MA 02543 \\ Phone: (508) 289-2945 \\ Fax: (508) 457-2194 \\ pjackson@whoi.edu \\ Carlos M. García \\ Instituto Superior de Recursos Hídricos \\ Universidad Nacional de Córdoba \\ Av. Filloy s/n. Ciudad Universitaria. \\ Córdoba, 5000, Argentina
}

Kevin A. Oberg

U.S. Geological Survey

Office of Surface Water

$1201 \mathrm{~W}$. University Ave.

Urbana, IL 61801, USA

Kevin K. Johnson

U.S. Geological Survey

Illinois Water Science Center

1201 W. University Ave.

Urbana, IL 61801, USA

Marcelo H. García

Dept. of Civil and Environmental Engineering

University of Illinois at Urbana-Champaign

205 North Mathews Ave.

Urbana, IL 61801, USA

\footnotetext{
${ }^{\dagger}$ Present Address: U.S. Geological Survey, Illinois Water Science Center, 1201 W. University Ave. Urbana, IL 61801, USA

Phone: (217) 344-0037 (ext. 3063)

pjackson@usgs.gov
} 


\section{Abstract}

Bidirectional flows in a river system can occur under stratified flow conditions and in addition to creating significant errors in discharge estimates, the upstream propagating currents are capable of transporting contaminants and affecting water quality. Detailed field observations of bidirectional flows were made in the Chicago River in Chicago, Illinois in the winter of 2005-06. Using multiple acoustic Doppler current profilers simultaneously with a water-quality profiler, the formation of upstream propagating density currents within the Chicago River both as an underflow and an overflow was observed on three occasions. Density differences driving the flow primarily arise from salinity differences between intersecting branches of the Chicago River, whereas water temperature is secondary in the creation of these currents. Deicing salts appear to be the primary source of salinity in the North Branch of the Chicago River, entering the waterway through direct runoff and effluent from a wastewater-treatment plant in a large metropolitan area primarily served by combined sewers. Water-quality assessments of the Chicago River may underestimate (or overestimate) the impairment of the river because standard water-quality monitoring practices do not account for density-driven underflows

18 (or overflows). Chloride concentrations near the riverbed can significantly exceed 19 concentrations at the river surface during underflows indicating that full-depth parameter 20 profiles are necessary for accurate water-quality assessments in urban environments where 21 application of deicing salt is common.

23 Key words: density current, gravity current, bidirectional flow, chloride, deicing salt, 24 Chicago River 


\section{Introduction}

The present-day Main Branch of the Chicago River (hereafter MB) flows west from Lake Michigan, through downtown Chicago, Illinois, and joins the North Branch (hereafter referred to as NB) where it empties into the South Branch (hereafter SB) (Figure 1). Flow in the MB was reversed in 1900 to keep sewage effluent from reaching Lake Michigan (Hill 2000). The MB flow is now controlled by the Lockport Powerhouse and Controlling Works near Joliet, IL, by the Chicago River Controlling Works (hereafter referred to as CRCW) and by the Chicago Harbor Lock at Lake Michigan. During summer, water from Lake Michigan flows into the MB through sluice gates and lockages (the passage of ships through the lock) at the $\mathrm{CRCW}$. This flow, called discretionary diversion, is used to preserve or improve the water quality in the MB, SB and the Chicago Sanitary and Ship Canal (hereafter referred to as CSSC). During winter, diversions from Lake Michigan into the $\mathrm{MB}$ are small compared to summer and typically result from lockages and leakage through the gates and sea walls at CRCW. The NB carries watershed runoff and treated municipal sewage effluent from the North Side Water Reclamation Plant located on the North Shore Channel, $16 \mathrm{~km}$ upstream from the MB. Sewage effluent accounts for as much as $75 \%$ of the discharge in the NB during winter months (Manriquez et al. 2005).

During routine discharge measurements in 1998 as part of the discretionary diversion accounting, the U.S. Geological Survey (USGS) observed bidirectional flow in the MB at station 7 (see Figure 1, Map A). Bidirectional flow consists of two layers moving in opposite directions (i.e. one layer flowing downstream while the other layer flows upstream). Such flow irregularities introduced large uncertainty into discharge 
1 measurements made at this station using an acoustic velocity meter and the index velocity

2 technique (Morlock et al. 2002). Motivated by the 1998 field observations, Bombardelli

3 and Garcia (2001) used a three-dimensional numerical model to test the hypothesis that

4 density currents (buoyancy-driven flows arising from density differences) created

5 bidirectional flows in the Chicago River. Whereas the duration and frequency of the

6 bidirectional flows were not known, the observed and modeled flows indicated the

7 possibility that water from the NB might be flowing into the $\mathrm{MB}$ and affecting water

8 quality. Concerns were also raised about the potential effects of these currents on the

9 water quality in Lake Michigan should the pump station located on the Chicago inner

10 harbor turning basin cutoff wall near the lock (see Fig. 1, Map A) ever be utilized. The

11 pump station was designed to return water to Lake Michigan from the Chicago River

12 during the period November to April to make up for excessive diversion from Lake 13 Michigan.

15 Based on data from an uplooking acoustic Doppler current profiler (ADCP) and available 16 meteorological and limited water-quality data for the period from November 2003 to 17 February 2004, García et al. (2007) concluded that bidirectional flows occurred in the MB 18 because of currents driven by differences in density $\rho$ between waters from the NB and 19 MB. They hypothesized that the density differences might be caused by temperature 20 differences, high concentrations of dissolved salts, suspended-sediment concentations, or 21 by some combination of these three factors. Bombardelli and Garcia (2001) proposed an 22 equation of state that accounted for the relative contribution of all these factors to density 23 differences in the Chicago River, and indicated that density underflows would be most 
1 common during the winter months. Garcia et al. (2007) found that bidirectional flows

2 were common in the Chicago River system; over a period of 2.5 months, 28 bidirectional

3 flow events were observed with underflows $\left(\rho_{\mathrm{NB}}>\rho_{\mathrm{MB}}\right)$ measured $47 \%$ of the time and 4 overflows $\left(\rho_{\mathrm{NB}}<\rho_{\mathrm{MB}}\right)$ measured $30 \%$ of the time.

5

6 Previous studies of bidirectional flow in the Chicago River have only speculated about the 7 source of the density anomaly in the river (Bombardelli and Garcia, 2001; García et al. 2007). The present work introduces a new set of synoptic field data recorded during bidirectional flow events in the Chicago River system. Data are used to validate previous hypotheses about the fluid properties of the density currents, to characterize the currents, and to propose possible sources of the dense water. Two density current events (an underflow and an overflow) are characterized based on data collected during field measurements performed in December 2005 and January 2006. In addition, an event in late January 2006 is presented showing the transition from an underflow to an overflow condition. The potential sources of the dense water are discussed and recommendations are given for future work.

\section{Data collection}

In December 2005, a field program was initiated by the USGS and the University of Illinois at Urbana-Champaign (UIUC) to investigate bidirectional flows in the Chicago River. Synoptic field measurements included velocity and water-quality profiles measured at seven locations in the Chicago River system (Table 1, Fig. 1). The profiles were collected on December 19, 2005, and on January 11, 2006, by measuring from bridge 
1 crossings. In addition, the temporal evolution of the velocity profile in the MB was

2 captured at station 7 using an uplooking ADCP.

4 Simultaneous velocity and water-quality profiles were measured at stations listed in Table

51 using (1) an Oceanscience River Boat equipped with a Teledyne RD Instruments 600

$6 \mathrm{kHz}$ ADCP and (2) a YSI data sonde. (The use of trade, product, or firm names in this

7 paper is for descriptive purposes only and does not imply endorsement by the U.S.

8 Government.) Velocity profiles were not recorded at all stations. The same ADCP

9 sampling configuration was adopted for all water-velocity measurements: a bin size of 0.10

$10 \mathrm{~m}$, a blanking distance of $0.25 \mathrm{~m}$, the ADCP submerged to about $0.09 \mathrm{~m}$, a pulse coherent

11 water-velocity measurement mode (mode 11), a sampling interval of between 0.6 and 0.64

$12 \mathrm{~s}$, and single ping configuration to obtain both the water velocity and boat velocity

13 measurements (one profile at station 7 used mode 12, $25 \mathrm{~cm}$ bins, and a sampling interval 14 of $0.99 \mathrm{~s})$.

16 Temperature and conductivity profiles were measured using a YSI Model 600xl multi17 parameter data sonde with a thermistor (range: $-5^{\circ}$ to $45^{\circ} \mathrm{C}$; accuracy: $0.15^{\circ} \mathrm{C}$ ) and a 4 18 electrode cell conductivity probe (range: 0 to $100 \mathrm{mS} / \mathrm{cm}$; accuracy: $0.5 \%$ of reading + $190.001 \mathrm{mS} / \mathrm{cm})$. A YSI 650 Multiparameter Display system allowed real-time display of the 20 temperature and conductivity readings refreshed every second. Profiles were recorded by

21 measuring at discrete points in the vertical and allowing enough time at each point for the 22 readings to stabilize. Vertical resolution of the measurements generally was limited to 0.6 $23 \mathrm{~m}(0.3 \mathrm{~m}$ at stations 5 and 6 on December 19,2005$)$ with an error in the depth of less than 
$10.5 \mathrm{~m}$ due primarily to layback (wire angle) of the graduated deployment wire while

2 sampling. Salinity was computed in accordance with national and international standards

3 (Clesceri et al. 1998; Fofonoff et al. 1983) under the assumption that sodium chloride

$4 \quad(\mathrm{NaCl})$ is the major constituent contributing to the high conductivity. This assumption is

5 reasonable because $\mathrm{NaCl}$ is the primary road salt used in the Chicago area (Friederici

6 2004) and elevated chloride concentrations (above background levels) in the NB have been

7 observed during winter (García et al., 2005). Density was computed using the United

8 Nations Educational, Scientific and Cultural Organization (UNESCO) 1983 equation of

9 state for seawater that is valid at the observed temperatures (Fofonoff et al. 1983). For

10 comparison, densities were also computed with a simplified equation of state used by

11 Bombardelli and Garcia (2001) resulting in slightly higher densities $(<0.1 \%$ difference).

12 The UNESCO 1983 equation of state was ultimately used to keep with recognized 13 standards.

15 The temporal evolution of the velocity profiles at station 7 was measured with an 16 uplooking $600-\mathrm{KHz}$ Teledyne RD Instruments ADCP deployed on the channel bottom 17 (from 6.7 to $6.8 \mathrm{~m}$ depth) along the approximate channel center line. An underwater cable 18 connected the ADCP to a computer in the nearby USGS streamflow-gaging station 19 (05536123), allowing full remote operation of the instrument including real-time data 20 access. This ADCP was deployed intermittently starting in August 1999 and has operated 21 continuously since May 2003 (with the exception of servicing periods). The uplooking 22 ADCP provided three component, continuous profiles of velocity at a sampling frequency 23 of $0.1 \mathrm{~Hz}$. The uplooking ADCP was configured using the mode 5 pulse-coherent 
1 technique for RDI profilers, $10 \mathrm{~cm}$ depth cells, and a $0.05 \mathrm{~m}$ blanking distance. The

2 deepest valid velocity measurement was approximately $0.40 \mathrm{~m}$ above the streambed and no

3 data in the top $1 \mathrm{~m}$ of the flow were used in this analysis because of side-lobe interference

4 and decorrelation near the surface (Simpson 2001). With these limitations, about $79 \%$ of

5 the depth in each profile contained valid water-velocity measurements. A temperature

6 sensor (range from $-5^{\circ} \mathrm{C}$ to $45^{\circ} \mathrm{C}$, precision of $0.4^{\circ} \mathrm{C}$, resolution of $0.01^{\circ} \mathrm{C}$ ) mounted

7 between the ADCP transducers $(0.3 \mathrm{~m}$ above the streambed) measured near-bed water

8 temperature at sampling frequency of $0.1 \mathrm{~Hz}$.

9

10 Data collected during this study allowed the characterization of the observed density

11 currents. Layer-averaged velocity $U$ and layer depth $H$ were computed using a set of

12 moments (García 1994, García et al. 2007) with the upper limit of the underflow taken as

13 the zero velocity line for the integration. Excess fractional density was computed as ( $\rho-$

$\left.14 \rho_{0}\right) / \rho_{0}$ (expressed as a percent) where $\rho$ and $\rho_{0}$ are the mean densities of the density current

15 and ambient water, respectively. The Reynolds number $\mathrm{Re}=U H / v$, the Richardson

16 number $\mathrm{Ri}=g^{\prime} H / U^{2}$, and the densimetric Froude number $\mathrm{Fr}=U /\left(g^{\prime} H\right)^{0.5}$ were computed,

17 where $v$ is the kinematic viscosity, $g^{\prime}=g\left(\rho-\rho_{0}\right) / \rho_{0}$ is the reduced gravity, and $g$ is the

18 gravitational acceleration. The density ratio, or the ratio of the contributions from

19 temperature and salinity to the density, was computed to determine the primary contributor

20 to the density anomaly driving these currents. The contribution to density from each scalar

21 was computed by taking the difference in density over the depth from each scalar while

22 holding the other scalar constant at its depth averaged value. 
1 Meteorological data from the National Climatic Data Center were analyzed to characterize

2 the boundary conditions present in the Chicago River system during the sampling period.

3 Data included time series of air temperature, wind speed, and wind direction reported

4 hourly by the O'Hare airport meteorological station (WBAN Station 94846, Chicago, IL).

6 3. Data analysis

7

3.1 Characterization of an Underflow Event: December 19, 2005

9 On December 19, 2005, an underflow event was observed in the main branch of the

10 Chicago River. The bidirectional flow data from the uplooking ADCP at station 7 for the

11 4-hour period starting at approximately 11:30 AM Central Standard Time (CST) is

12 presented in Figure 2b. The velocity data indicate a sustained underflow with a thickness

13 of about $2 \mathrm{~m}$ and a layer-averaged velocity of approximately $3 \mathrm{~cm} / \mathrm{s}$ traveling east toward

14 Lake Michigan and the surface flow to the west at approximately $2 \mathrm{~cm} / \mathrm{s}$. There is 15 excellent agreement between the time-averaged uplooking ADCP profile and the synoptic

16 velocity profile from the tethered boat (Figure 2b). The sampling period used in averaging

17 the uplooking ADCP data (from 11:32:28 to 15:24:08, 1391 ensembles) included the 6.5-

18 minute long sampling period (620 ensembles) for the tethered boat (starting at 12:05:00).

19 Southwesterly winds (winds originating from the southwest) prevailed throughout the data

20 record with speeds ranging between $9-14 \mathrm{mph}(14.5-22.5 \mathrm{~km} / \mathrm{h})$ and may be responsible

21 for the brief eastward surface flows. Air temperatures remained near $-13^{\circ} \mathrm{C}$ during the 22 sampling period. With the exception of small areas near the lock at Lake Michigan (Fig. 1, 23 Map A), no ice coverage was observed on the river. 
1 Water-quality profiles confirm the NB is the source of the dense water driving the

2 underflows in the MB of the Chicago River. Profiles of temperature, salinity, density and

3 downstream velocity for most of the stations listed in Table 1 (Table 1 includes sample

4 location information and sample times for each profile) are illustrated in Figure 3. The

5 collapse of the temperature and salinity profiles near the streambed reveals warm, saline

6 water from the $\mathrm{NB}$ invading the $\mathrm{MB}$ as an underflow. General flow circulation within

7 density currents pumps dense water to the head of the current along the lower boundary

8 while most of the mixing takes place at the front of the current and along its upper

9 boundary (Garcia and Parker 1993; Kneller et al. 1999). The relatively fresher, colder

10 water in the density current at station 7 and the observation of a flow reversal below the

11 velocity maximum in the current (see Fig. 3) indicates that the profile at station 7 may have

12 been taken close to the front of the current where entrainment (dilution) and mixing take

13 place. Temperature records from the uplooking ADCP at station 7 (Fig. 2a) indicate that

14 the water temperature near the bed in the MB rose to levels consistent with NB upper layer

15 water within several hours following the collection of water-quality profiles. This

16 observation not only directly links the water masses in the NB and the underflow, but it

17 also indicates that the underflow observed at station 7 is evolving and has not yet reached

18 equilibrium conditions. The collapse of the water-property profiles in the underflow in

19 Figure 3 indicates that lower quality water from the NB (relative to the MB) is capable of

20 reaching the lock at Lake Michigan with little dilution; such a density current can

21 negatively affect water quality in the Chicago River and, potentially, Lake Michigan. 
1 In contrast to the relatively uniform water properties of the underflow at all stations

2 (station 7 excluded), the ambient water properties show a horizontal (stream-wise) gradient

3 along the length of the MB with the densest water in the NB and the lightest water at

4 station 7. This horizontal density variation is a direct result of mixing between $\mathrm{MB}$ and

5 NB water. Near the confluence, the MB mixes more efficiently with NB water compared

6 to the reach close to the lake creating stream-wise gradients. Influx of fresh water from

7 Lake Michigan (leakage, lockage, diversion) can strengthen this horizontal gradient.

9 While stations 1 and 2 in the NB display uniform water-quality profiles, station 3 just

10 upstream from the confluence with the MB shows signs of mixing between NB and MB

11 water. This result indicates that the plunging point for this underflow, the point at which

12 the dense water plunges below the lighter water creating a flow convergence (see García et

13 al. 2007), was upstream from station 3 and downstream from station 2. Field notes taken

14 during measurements on December 19, 2005, indicate a line of debris on the water surface

15 between stations 2 and 3. The flow convergence associated with the plunging point would

16 form such a debris line at the location of plunging (Largier 1992).

18 The depth of the velocity interface (the zero velocity point) for each profile approximately

19 coincides with the mean of the density profile and the middle of the interfacial layer in

20 density. The broad and almost linearly stratified interfacial region indicates relatively

21 strong mixing at the head of the density current and a wake region behind the head in

22 which the scalar concentrations linearly vary (Britter and Simpson 1978; Parsons and

23 Garcia 1998; Kneller et al. 1999; Cantero et al. 2007). Effects of the no-slip boundary 
1 condition imposed by the lower boundary and the influence of a wind-induced surface

2 stress at the upper boundary are also seen in Figure 3. For clarity, the velocity profile from

3 station 2, which had a mean downstream velocity of about $3 \mathrm{~cm} / \mathrm{s}$ and showed no signs of

4 bidirectional flow, has been omitted from Figure 3.

6 The observed underflow was subcritical $(\mathrm{Fr}<1)$ with increasing Froude numbers towards

7 the head of the current (Table 2A). The relatively low Froude numbers observed within

8 the body of the current indicate buoyancy-dominated flow and are consistent with the

9 Froude numbers measured in the saline density current of Fernandez and Imberger (2006)

10 under equilibrium conditions. The increase in the Froude number (decrease in $\mathrm{Ri}$ ) at

11 station 7 indicates that the current may not have been under equilibrium flow conditions at

12 station 7 during sampling, an assumption made by (García et al. 2007) to estimate the

13 excess density of a strong underflow event from a different set of water velocity

14 measurements. The higher Froude number (lower Ri) at station 7 indicates a greater rate of

15 entrainment and mixing characteristic of the front of a density current. Previous

16 measurements (García et al. 2007) may have been made farther from the head of the

17 current where equilibrium conditions could be achieved. However, the Froude number at

18 station 7 in the present observations was less than unity (characteristic of critical flow

19 conditions at the front (e.g. Garcia and Parsons 1996)) indicating that the observations

20 were made in the body of the current, but prior to reaching equilibrium conditions.

22 Bombardelli and Garcia (2001) observed an increase in the excess fractional density along 23 the length of the MB from the confluence to the lock. The present observations show a 
1 similar trend (Table 2A, Fig. 3). With the exception of station 7, the density change over

2 the channel depth increases from station 1 to station 6 (Fig. 3) and station 7 would have

3 likely been similar had the profile been taken under equilibrium conditions. The increase

4 in the excess density along the current from the tail to the head is a result of two factors: 1)

5 the efficiency of the current in pumping dense water to the head as demonstrated by the

6 collapse of the scalar profiles in the underflow, and 2) the stream-wise gradient in the

7 ambient water density along the length of the MB resulting from mixing. The ambient

8 water in a small volume receiving body such as the MB can become tainted by intruding

9 density currents leading to an increase in the excess fractional density toward the head.

10 However, many density currents issuing into large, uniform ambient environments show a

11 decrease in the excess density towards the head of the current because of entrainment and

12 mixing (e.g. Fernandez and Imberger 2006).

13

14 The low density ratios computed for this underflow (i.e. $R_{\rho}<0.1$ ) reveal that the density 15 differences are mainly due to salinity rather than temperature. The saline contribution to 16 the density is between 10 and 250 times the thermal contribution. Temperature only 17 minimally affects the density change because the temperatures in the upper and lower 18 layers straddle the $4^{\circ} \mathrm{C}$ density maximum for pure water (slightly lower for the brackish 19 water in the MB) leading to only small density differences because of temperature (e.g. 20 station 6). The temperature profiles at stations 5 and 6 were unstably stratified (identified

21 by a negative thermal contribution to the density change in the computation of the density 22 ratio) and salt acted to stabilize the density profile (Bombardelli and Garcia (2001) 23 observed similar scalar profiles). This result indicates that double diffusive mixing 
1 processes often observed in the ocean may be important in the Chicago River system

2 (Turner 1973, Parsons and García 2000).

4 Finally, analysis of five grab samples collected between 0930 and 1020 on December 19, 52005 , using a Niskin bottle in both the underflow and the ambient upper layer reveal

6 higher chloride concentrations at station $1(430 \mathrm{mg} / \mathrm{L})$ and in the underflow at station 7

$7 \quad(284 \mathrm{mg} / \mathrm{l})$ and lower concentrations in the upper layer water at station $7(147 \mathrm{mg} / \mathrm{l})$.

8 Station 8 on the shore of Lake Michigan had a chloride concentration of $15 \mathrm{mg} / \mathrm{l}$. Cation

9 analysis was not performed because of limited sample size. Recall that synoptic

10 measurements were made at station 7 prior to the underflow reaching an equilibrium state.

11 Following the synoptic measurements, the temperature of the underflow at station 7

12 increased through the day to eventually match the temperature of the NB water (Fig. 2a).

13 These temperature observations combined with the collapse of the temperature and salinity 14 profiles within the underflow at all other stations (Fig. 3) indicates that the near-bed 15 chloride concentration at station 7 may have increased through the day to match the NB 16 chloride concentration $(430 \mathrm{mg} / \mathrm{l})$. Chloride concentrations in the observed underflow 17 were about a factor of 1.9 (and perhaps up to a factor of 3) higher than upper layer 18 concentrations. The potential sources of salt and the implications of the vertical chloride 19 gradient for routine sampling procedures are discussed further in Section 4 of this paper.

213.2 Characterization of an Overflow Event: January 11, 2006

22 Simultaneous water-quality and velocity profiles captured an overflow event in the 23 Chicago River on January 11, 2006. The velocity time series from the uplooking ADCP is 
1 compared with the synoptic velocity profile at station 7 in Figure $4 \mathrm{~b}$. Water temperatures

2 in the NB and MB during the sampling period are shown in Figure 4a. In contrast to the

3 December 19, 2005, underflow event (previous section), the bidirectional flow on this day

4 was primarily upstream flow (to the lake) at the surface and downstream flow near the

5 bottom. The early part of the record shows an intrusion with weak upstream velocities of

6 about $1 \mathrm{~cm} / \mathrm{s}$ near mid-depth bounded by downstream flows near the top and bottom. The

7 low-flow profile during this period was captured well by the uplooking ADCP, but the

8 tethered boat failed to resolve the intrusion. This result highlights the benefits of a bottom-

9 mounted uplooking ADCP for low and variable flow situations. By midday, the flow

10 transitioned to a $3.5 \mathrm{~m}$ thick overflow that gradually increased in strength before peaking at

11 about 14:00. Winds varied in speed from 9 to $15 \mathrm{mph}(14.5$ to $24.1 \mathrm{~km} / \mathrm{h})$ throughout the

12 day with southwesterly winds in the morning followed by southerly winds in the afternoon.

13 While winds may have triggered the upstream surface flows early in the day, the relatively

14 strong overflow late in the day is inconsistent with wind forcing. Winds of a similar speed

15 and direction were observed on December 19, 2005, and January 24, 2006, and no

16 sustained overflow events occurred in those records. Air temperatures remained about $4{ }^{\circ} \mathrm{C}$

17 throughout the sampling period. No ice was present in the Chicago River system at the

18 time of the measurements.

20 The scalar profiles measured during the overflow event showed similar trends to those

21 measured during the December 19, 2005, underflow event, in spite of opposite directions

22 of the currents. Profiles of temperature, salinity, density and velocity are shown at various

23 locations along the $\mathrm{NB}, \mathrm{MB}$, and $\mathrm{SB}$ of the Chicago River in Figure 5. Similar to the 
1 underflow event, the water in the $\mathrm{NB}$ was warmer than the water in the MB for the

2 overflow. A temperature drop from the NB to the MB seems to be a common occurrence

3 in the Chicago River system (García et al. 2007). The temperature change between these

4 two reaches was comparable to that during the December 19,2005 , underflow (4 to $5^{\circ} \mathrm{C}$ );

5 however, the water temperatures were above the $4^{\circ} \mathrm{C}$ density maximum allowing the

6 temperature difference to control more of the density change. With the exception of the

7 bottom water at station 7, the salinity also generally decreased moving from the NB to the

8 MB. This, too, is similar to the observed underflow event; however, the change in salinity

9 along the river was only about $20 \%$ of that during the December 19,2005 underflow event.

10 At station 7, the deep water was relatively saline (compared to the rest of the Chicago

11 River system); a likely result of the lateral trapping of lower quality, dense water from 12 previous underflow events and local runoff. Water-quality measurements by the

13 Metropolitan Water Reclamation District of Greater Chicago near the lock (Fig. 1, Map A, 14 WQ74) show a gradual increase in the chloride concentrations in the MB throughout the 15 winter (see Section 4, Fig. 7) indicating trapping of dense water and insufficient flushing 16 by Lake Michigan water during winter.

18 In contrast to the December 19, 2005 underflow event, the density profiles for this 19 overflow event reveal a density increase from the NB to the MB. The density was lower in 20 the NB despite the fact that water in the NB had a higher salinity because temperature 21 controlled the density stratification (noted by a density ratio above unity, see Table 2B).

22 As the overflow reached the MB, the trapped dense water in the MB was replaced by less 23 dense NB water resulting in partial flushing of the MB. The scalar profiles do not collapse 
1 in the upper overflow layer indicating that there was appreciable entrainment and mixing

2 along the overflow acting to dilute the current along its stream-wise axis (in contrast to the 3 underflow on December 19, 2005, which showed little dilution). However, such an

4 observation could also result from the unsteadiness of the current over the period of the 5 synoptic measurements (see Fig. 4).

6

7 The synoptic velocity profiles in the MB (stations 5 and 6) show an overflow toward the 8 lake with interfacial depths of about $1.4 \mathrm{~m}$ and $2.4 \mathrm{~m}$, respectively, whereas the mean 9 overflow thickness at station 7 based on the uplooking ADCP data was about $3.5 \mathrm{~m}$ (Fig. $104 \mathrm{~b})$. The variability in the thickness of the overflow along the MB is attributed to the 11 unsteadiness of the current over the sampling period. The synoptic velocity profile at 12 station 7 (Fig. 4b) had numerous flow reversals with layer depths of about 0.5 to $1.5 \mathrm{~m}$ 13 possibly indicating interleaving (the temperature profile at station 7 was unstable 14 indicating potential double diffusive processes). Interleaving is the dovetailing of two 15 water masses along a front separating the masses creating an alternating series of intrusions 16 of one mass into the other. Whereas the tethered-boat profile at station 7 was ultimately 17 inconclusive because of the low velocities and poor vertical resolution, the uplooking 18 ADCP data show alternating layers of upstream and downstream flow consistent with 19 interleaving (Fig. 4b). Mean layer thicknesses were from 1 to $1.5 \mathrm{~m}$, slightly larger than 20 those seen in the synoptic measurements. The resolution of the density profile is far too 21 low to verify the existence of steps in the profile consistent with these layers. 
1 Finally, data from station 1 indicate an underflow in the NB progressing upstream during

2 the overflow event in the MB. Just as the plunging point in the underflow draws MB water

3 along the surface upstream in the NB, the "rising point" for the overflow has similar

4 tendencies. In this case, relatively dense water may have been drawn upstream along the

5 bottom of the NB by the entrainment associated with the detachment and rising of the

6 overflow. The density signature of this underflow is virtually undetectable compared to

7 the stronger events in the MB, perhaps because of the enhanced mixing along the bottom

8 boundary combined with the relatively weak excess density. The density ratio at station 1

9 was very low (Table $2 \mathrm{~b}$ ) indicating that the excess density of the underflow at this station

10 was primarily due to salt. No bidirectional flows were observed downstream from the

11 confluence at station 9 (Fig. 5).

13 Characterization of the overflow event reveals a much weaker, more diluted density 14 current compared to the December 19, 2005, underflow event (Table 2). The excess 15 fractional density was an order of magnitude smaller than the observed underflow event. 16 The small and decreasing Richardson number (increasing Froude number) along the 17 current indicates greater entrainment and mixing; thus, supporting the previous observation 18 of a less homogeneous current in terms of water properties. Station 6 appeared to be close 19 to the head of the overflow as the Richardson number and Froude numbers approached 20 unity and the current was relatively thin (and nonexistent at station 7 for the time of the 21 profiling). 
1 The density ratios observed in the $\mathrm{MB}$ for the overflow event reveal that temperature

2 controlled the density stratification at station 5 and temperature and salinity equally

3 contributed to the density stratification at station 6. At station 7 (not shown in Table $2 b$ )

4 the high salinity water near the bed controlled the density stratification and temperature

5 was unstably stratified. This stream-wise variation in density ratio (temperature controlled

6 density stratification in the MB near the confluence and salinity controlled the stratification

7 near the lock) likely arose from the trapping of dense, saline water in the MB during

8 previous underflow events. The water near the confluence was flushed relatively easily

9 compared to the water near the lock ( $2.5 \mathrm{~km}$ away from the confluence) resulting in a 10 gradual increase in salinity along the MB.

11

12 13

\subsection{Transition from an Underflow to an Overflow: from January 23, 2006, to January 27,} 2006

The December 19, 2005, and January 11, 2006, events described above document a variable and fluctuating density in the NB of the Chicago River. As "slugs" of dense water are transported down the NB to the SB of the Chicago River, the MB acts as a lateral trap for the dense water. These slugs of dense water may be well defined or diffuse with a long leading edge and trailing tail in response to mixing and shear dispersion upstream. Under the right conditions, a well-defined slug will lead to a sharp transition between an underflow and an overflow as seen in Figure 3 of García et al. (2007), whereas a diffuse slug will form a well-defined intrusion in the transition from an underflow to an overflow (García et al. 2007, Fig. 8). 
1 Based on past water-velocity data, intrusions often mark the transition from an underflow

2 event to an overflow event in the Chicago River. The transition of an underflow to an

3 overflow for the period from January 23, 2006, to January 27, 2006, captured by the

4 uplooking ADCP at station 7 is shown in Figure 6. One possible explanation for this 3.5-

5 day transition is a gradual decrease in the density of the NB water and the gradual increase

6 in the density of the MB water through mixing. We hypothesize that at the point when the

7 underflow detached from the bottom (about 00:00 on January 25, 2006), the density of the

8 NB water reached a density equal to that of the MB bottom water. Further decreases in the

9 density of the NB water led to the subsequent propagation of an intrusion into the MB at

10 the level of neutral density (the density at which the intrusion is neither positively or

11 negatively buoyant). The level of neutral density decreased in depth as the water in the NB

12 continued to decrease in density until the point at which the NB water was lighter (less

13 dense) than the MB water and an overflow formed. Moreover, the horizontal gradients in 14 density throughout the MB (Figs. 3 and 5) likely caused the current to continually adjust its

15 position in the water column as it traveled along the MB and searched for the level of 16 neutral density.

18 At the present time, there is insufficient instrumentation and a lack of data to verify the 19 transition behavior as theorized above. No concurrent time series of the velocity in the $20 \mathrm{MB}$ and density stratification in the NB exist. However, the two events described in this 21 paper capture the two states of the Chicago River system-an underflow $\left(\rho_{\mathrm{NB}}>\rho_{\mathrm{MB}}\right)$ and 22 an overflow $\left(\rho_{\mathrm{NB}}<\rho_{\mathrm{MB}}\right)$. Based on this evidence, there must be a state at which the NB 23 water has a density equal to that at mid-depths in the stratified MB. At this point an 
1 intrusion would form and propagate in the MB along the neutral density surface. The

2 duration of the intrusion is dependent on the strength of the stratification in the MB and the

3 time rate of change of density in the NB.

4

5 García et al. (2007) hypothesized that wind has an effect on the thickness of an underflow.

6 The eastward surface flow in the middle of the velocity record illustrated in Figure 6

7 appears to be a result of westerly winds at sustained speeds of 15-25 mph (Fig. 6a). While

8 it may be fortuitous, the underflow ceases as the winds shift from southerly to westerly and

9 proceeds again when the winds shift to the northwest. Wind can generate turbulence that is

10 capable enhancing the mixing and entrainment at the density current interface (Kranenburg

11 1985). The eastern surface flows penetrated down to a depth of $4 \mathrm{~m}$, thinning the current

12 and apparently disabling the underflow (Fig. 6). As the wind-induced flow at the surface

13 varied, the current appears to have responded. Periodic reattachment of the intrusion to the

14 bottom after the initial separation appears to be correlated with the relaxing of the wind-

15 driven eastward (upstream) surface currents. The response of the system to wind forcing

16 indicates that seiching may be an important factor in the dynamics of density currents in

17 this partially closed system (partially closed by the lock at Lake Michigan), although the

18 velocity profiles are inconsistent with purely wind-driven currents (Bombardelli and

19 Garcia 2001). More simultaneous observations of wind conditions in the presence of

20 bidirectional flows are needed to assess the effect of wind on bidirectional flows, including

21 its effect on mixing in the Chicago River. 


\section{1}

2

8 The most probable ways in which salt can be introduced to the NB is through 1) direct

9 runoff of deicing salts, 2) effluent from wastewater-treatment plants, and 3) industrial

10 discharge. Naturally occurring salt loading such as weathering of chloride-rich rocks is

11 unlikely in this area of the country. Repeated measurements by MWRDGC show that the

12 highest chloride concentrations are present in the NB upstream from the North Shore

13 channel (i.e. upstream from any lake diversions) in winter and the lowest concentrations

14 are observed in summer (Fig. 7). Natural weathering and routine municipal and industrial

15 effluent would produce a less variable load throughout the year. The seasonal variability

16 in the chloride concentration is consistent with direct runoff of deicing salts to surface

17 water and combined sewer systems (Kaushal et al. 2005). Chloride concentrations in the

18 MB of the Chicago River increase over the winter when lockages and diversions are at a

19 minimum (Fig. 7). Lock exchanges and discretionary diversion flush the MB causing

20 chloride concentrations to rapidly decrease when lock exchanges become more frequent in

21 early spring. In contrast, reaches upstream from lake diversions can have chloride

22 concentrations near or above the U.S. Environmental Protection Agency's 2006

23 recommended chronic chloride criterion ( $230 \mathrm{mg} / \mathrm{l}$, USEPA 2006) even in summer (Fig. $247)$. 
1 More than 140,000 tons of deicing salts (primarily $\mathrm{NaCl}$ ) are applied to the six-county area

2 making up greater Chicago in a given year (Friederici 2004). Of that salt, about 55\% is

3 transported to surface water by runoff and the remainder is left to infiltrate the soil and

4 groundwater (Church \& Friesz 1993). In areas like Chicago that are served by combined

5 sewers, much of the runoff and associated deicing salts are collected and contained in the

6 effluent from the water-reclamation plants. Weekly and monthly water-quality

7 measurements by the MWRDGC in the North Shore Channel at the outfall of the North

8 Side Water Reclamation Plant (WQ1) and upstream from the outfall (WQ102) show high

9 chloride concentrations in winter at both sites (Figs. 1 and 7). The winter chloride

10 concentrations upstream from the plant generally equaled (or on one occasion exceeded)

11 the outfall concentrations indicating significant chloride contamination upstream from the

12 plant (Fig. 7), perhaps a result of direct runoff of deicing salts or density currents

13 propagating upstream from the outfall. The chloride concentration dropped significantly in

14 summer upstream from the plant to levels consistent with concentrations in Lake Michigan

15 water (about $15 \mathrm{mg} / \mathrm{l}$ ). The flushing of the North Shore Channel during summer months is

16 consistent with increased discharge at the lake front because of discretionary diversion of

17 Lake Michigan water by the Wilmette Pumping Station (Duncker et al. 2006).

19 In the NB and its tributaries, impairment is caused, in part, by high total dissolved solids

20 and/or chlorides (Fig. 8, Illinois Environmental Protection Agency 2004). One of the

21 primary sources of impairment is urban runoff/storm sewers (Illinois Environmental

22 Protection Agency 2004). Other sources include municipal point sources and combined

23 sewer overflows. Along with other pollutants and chemicals, deicing salts are directly 
1 entering the NB and its tributaries via urban runoff and combined sewage effluent. The

2 low winter discharge allows chloride to accumulate in the upstream tributaries (Fig. 7).

3 During periods of increased flow, such as precipitation periods and snowmelts, chloride-

4 rich water can be flushed downstream creating a density anomaly (Marsalek 2003).

5 Evidence of insufficient flushing can be seen in Figure 7 during the summer of 2005 when

6 chloride concentrations in the upstream reaches of the NB remained excessively high (well

7 above the U.S. Environmental Protection Agency's 2006 chronic chloride recommendation

8 of $230 \mathrm{mg} / \mathrm{l}$ ). Spring through fall of 2005 was the driest on record for the Chicago area and

9 this followed the $8^{\text {th }}$ wettest January on record where significant snowfall likely increased 10 salt use.

12 Based on the above evidence, the authors hypothesize that the main source of the high 13 chloride (saline) water in the NB may be the direct runoff of deicing salts to upstream 14 reaches (primarily the Skokie River, the West Fork of the North Branch, and the Middle 15 Fork of the North Branch) and chloride-rich effluent from the North Side Water Treatment 16 Plant in the North Shore Channel. Numerous impoundments of water are present along the 17 northern reaches of the watershed and may act as salt storage reservoirs during the winter 18 (Marsalek 2003). Underflow events that have been observed before the first snowfall of 19 the year (before deicing begins) (García et al. 2007) may be due to releases of chloride-rich 20 water during precipitation periods. Evidence of this chloride storage is seen in Figure 7 as

21 NB chloride concentrations are between 4 and 16 times greater than those concentrations

22 in the MB during summer months. Whereas the reaches upstream from the North Shore

23 Channel have some of the highest chloride concentrations in the system, the North Shore 
1 Channel appears to have a significant contribution to the total chloride load in the NB

2 because of its high concentrations and discharge. Analysis of the weekly and monthly

3 water-quality measurements can lend insight into the sources of chloride-rich water, yet

4 one must use caution when comparing the results to formation of density currents that have

5 a time scale on the order of days. To truly determine the primary sources of the saline

6 water, daily water-quality samples are needed in conjunction with discharge estimates.

8 Sharp gradients in salinity that accompany the density currents in the MB and confirmation

9 that the currents are composed of NB water raises concerns about water-quality

10 assessments of the Chicago River. Water-quality samples in the Chicago River are

11 currently collected just below the surface and are used by the U.S. Environmental

12 Protection Agency for water-quality assessments. Because there are higher water-quality

13 standards for the MB than the NB and SB (primary as opposed to secondary contact), it is

14 important that the water-quality assessment be accurate. However, these results indicate

15 that samples taken at the surface do not accurately represent the water quality within the

16 stratified MB because of the intrusion of density currents. Conductivity and chloride

17 measurements presented above show that underflows can have concentrations that exceed

18 surface water by a factor of 3 (and perhaps greater) and other constituents would likely

19 have a similar vertical distribution. Whereas surface water may meet recommended water-

20 quality standards, near bed water may significantly exceed these standards leading to

21 underestimation of the impairment of the Chicago River. While the impacts of these

22 currents on aquatic life are currently unknown, concentrations of chloride-rich water at and

23 near the river bottom will likely have the greatest effect on benthic species. Inland urban 
1 waterways in northern communities that apply road salt for deicing may need to modify

2 their sampling procedures to include deep, near-bed water samples and vertical parameter

3 profiles to accurately assess the water quality.

5 More work needs to be done to evaluate the mechanisms triggering initiation of density

6 currents in the Chicago River system. While it is clear that density plays the primary role

7 in driving these currents, wind and air temperature may be important in initiating, and

8 perhaps opposing, the currents. Climate data indicate that neither wind nor air temperature

9 can be solely responsible for driving all the observed currents, although more localized

10 observations are needed. A significant amount of data has yet to be analyzed and these

11 data, when combined with meteorological data, may provide answers to the remaining

12 questions concerning the effect of atmospheric forcing in density current formation. In

13 addition, a better understanding of the mixing and exchange of waters between the NB and

14 the MB could be determined from a tracer or dye release study combined with high spatial

15 and temporal resolution water-quality and velocity profiles. Tagging the NB water with

16 dye prior to plunging and tracking the dye as it moves through the system would be a

17 useful tool to understand and quantify mixing, exchange and retention in this system.

18 Placement of thermistor and conductivity strings in the NB and MB of the Chicago River

19 would provide much needed information about the temporal variability and evolution of

20 the density in these branches and would aide in assessing the role of seiching in the

21 generation of bidirectional flows. Finally, a continuation of the modeling effort started by

22 Bombardelli and García (2001) using recent observations and data sets to initialize and

23 force the system would complement the field observations and provide a means to analyze 
1 the sensitivity of the Chicago River system to atmospheric forcing, boundary conditions,

2 internal hydraulics, and lockages.

3

\section{Acknowledgements}

22 The authors greatly appreciate the support provided by USGS, Office of Surface Water 23 (Hydroacoustics Program), the Metropolitan Water Reclamation District of Greater

24 Chicago (MWRDGC), the USGS Illinois Water Science Center. We also thank the 25 MWRDGC and the U.S. Army Corps of Engineers for providing data used in this study 
1 and Woods Hole Oceanographic Institution's Postdoctoral Scholar Program for providing

2 salary support for P.R. Jackson during the writing of this paper.

\section{References}

5 Bombardelli, F. A., and García, M. H. Three-dimensional hydrodynamic modeling of 6 density currents in the Chicago River, Illinois, Hydraulic Engineering Series Report No. 68, Civil Engineering Studies, University of Illinois at Urbana-Champaign, Illinois, 2001, 73 pp.

9

$11 \quad$ Fluid Mech 1978; 88: 223-240.

Cantero, M.I., Lee, J.R., Balachandar, S., and Garcia, M.H. On the front velocity of gravity currents. J Fluid Mech 2007; 586: 1-39.

Clesceri, L.S., Greenberg, A.E., and Eaton, A.D. Standard Methods for the Examination of Water and Wastewater, $20^{\text {th }}$ ed., American Public Heath Association. Washington, D.C, 1998. pp. 2-48-2-50.

Church, P. E. and Friesz, P. J. Effectiveness of Highway Drainage Systems in Preventing Road-Salt Contamination of Groundwater: Preliminary Findings. Trans Res Rec 1993; 
1 Duncker, J.J., Over, T.M., and Gonzalez, J.A. Computation and error analysis of discharge

2 for the Lake Michigan Diversion Project in Illinois: 1997-99 Water Years: U.S.

3 Geological Survey Scientific Investigations Report 2006-5018, 2006; 70 pp.

4

5 Fernandez, R.L. and Imberger, J. Bed roughness induced entrainment in a high Richardson

6 number underflow. J Hydraulic Res 2006; 44(6): 725-738.

7

8 Fofonoff, P. and Millard, R.C. Jr, UNESCO Algorithms for computation of fundamental

9 properties of seawater, 1983. UNESCO Tech Pap Mar Sci 1983; 44: 1-53.

10

11 Friederici, P. Salt on the Earth. Chicago Wilderness Magazine. Winter 2004.

12

13 Garcia, M.H., and Parker, G. Experiments on the Entrainment of Sediment into Suspension by

14 a Dense Bottom Current, J Geophys Res (oceans) 1993; 98(C3): 4793-4807.

15

16 García, M.H. Depositional turbidity current laden with poorly sorted sediment. J of Hyd $17 \quad$ Engr 1994; 120(11): 1240-1262.

18

19 Garcia, M.H., and Parsons, J.D. Mixing at the Front of Gravity Currents, Dynamics of 20 Atmospheres and Oceans 1996; 24: 197-205. 
1 García, C.M., Manriquez, C., Oberg, K., and García, M.H. Density currents in the Chicago 2 River, Illinois. In: Proceedings of the $4^{\text {th }}$ River Coastal and Estuarine Morphodynamics 3 Conference, G. Parker and M.H. Garcia (Editors), Urbana, Illinois, USA, 2005.

4

5 García, C.M., Oberg, K.A., and García M.H. (2007) ADCP Measurements of Gravity 6 Currents in the Chicago River, Illinois. J Hyd Engr 2007; 133(12): 1356-1366.

7

11 Illinois Environmental Protection Agency. Illinois 2004 Section 303(d) List. IEPA, 12

Hill, L. (2000) The Chicago River: a natural and unnatural history. Lake Claremont Press, Chicago, IL, 203 pp.

IEPA/BOW/04-005, Springfield, IL, 2004.

Kaushal, S.S., Groffman, P.M., Belt, K.T., Stack, W.P., Kelly, V.R., Band, L.E., and 5 Fisher, G.T. Increased salinization of fresh water in the northeastern United States. 6 Proceedings of the National Academy of Sciences 2005; 102(38): 13,517-13,520.

\section{7}

8

Kneller, B.C., Bennett, S.J., and McCaffrey, W.D. Velocity structure, turbulence and fluid stresses in experimental gravity currents. J Geophys Res 1999; 104: 5381-5391. 0

1 Kranenburg, C. Mixed-layer deepening in lakes after wind setup. J of Hyd Engr 1985; 111(9): 1279-1297. (1) 
1 Largier, J.L. Tidal Intrusion Fronts. Estuaries 1992; 15(1), Recent Advances in Estuarine

2 Science: Symposium Papers from the Tenth Biennial International Estuarine Research 3 Conference: pp. 26-39.

4

5 Manriquez, C.P., García, C.M., Jackson, P.R., and García, M.H. Hydraulic Model Study

6 of Chicago River Density Currents, Civil Engineering Studies, Hydraulic Engineering

7 Series No 77, University of Illinois at Urbana-Champaign, Illinois, 2005.

8

9 Marsalek, J. Road salts in urban stormwater: an emerging issue in stormwater management 10 in cold climates. Water Sci Tech 2003; 48: 61-70.

12 Morlock, S.E., Nguyen H.T., and Ross J.H. Feasibility of Acoustic Doppler Velocity 13 Meters for the Production of Discharge Records from U.S. Geological Survey 14 Streamflow-Gaging Stations. U.S. Geological Survey Water-Resources Investigation 15 Report 01-4157. Indianapolis, 2002.

16

17 Parsons, J.D. and García, M.H. Similarity of Gravity Current Fronts, Physics of Fluids 1998; $18 \quad 10(12): 3209-3213$.

19

20 Parsons, J.D. and García, M.H. Enhanced Sediment Scavenging due to Double-Diffusive 21 Convection, Journal of Sedimentary Research 2000; 70(1): 47-52. 
1 Simpson, M.R. Discharge measurements using a Broad-Band Acoustic Doppler Current 2 Profiler. U.S. Geological Survey Open-File Report 2001; 01-01, 123 p.

3

4 Turner, J.S. Buoyancy effects in fluids. Cambridge Univ. Press, Cambridge, U.K. 1973, $5 \quad 367 \mathrm{pp}$.

6

7 United States Environmental Protection Agency, National Recommended Water Quality 8 Criteria, Office of Science and Technology, 4304T, 2006. 
Figure 1. The Chicago River system, Chicago, Illinois. Circles on Map A show locations and identification of sampling stations (see Table 1) and squares show locations and identification of MWRDGC water-quality sampling stations (see Section 4).

Figure 2. December 19, 2005, underflow event. (a) Water temperature in the NB at station 1 (blue line, surface; red line, near bed) and MB at station 7 (black line, near bed). Near bed (YSI) water temperatures are also shown for most stations (symbols given in table 1). Station $3(\times)$ measurement was made from the bank at $4.75 \mathrm{~m}$ depth. (b) Contour plot of downstream water velocity (in $\mathrm{cm} / \mathrm{s}$ ) recorded by the uplooking ADCP at station 7 for an underflow event. The downstream direction is away from the lake (west). Mean downstream water-velocity profiles recorded at station 7 by both the uplooking ADCP (squares; averaged over the entire record shown) and the tethered ADCP (circles; averaged over 6.57 minutes starting at 12:05) are overlaid. Vertical blue lines show the time limits of the synoptic YSI measurements at station 7 (which encompass the tethered boat velocity profiles).

Figure 3. Water-quality and velocity profiles at stations along the Main Branch and North Branch of the Chicago River during the December 19, 2005, underflow event. Station locations are given in Figure 1, Map A. Velocity is given with the downstream (ds) component taken as positive. Single point samples for Lake Michigan (at $1.3 \mathrm{~m}$ depth; station 8): $\mathrm{T}=0.06{ }^{\circ} \mathrm{C}, \mathrm{S}=0.315 \mathrm{PSU}$ (Practical Salinity Units), $\rho=1000.108 \mathrm{~kg} / \mathrm{m}^{3}$. The 
sampling periods for the velocity measurements at stations 5, 6 and 7 were $10.17 \min$ (957 ensembles), $13.35 \min$ (1266 ensembles), and $6.57 \min$ (620 ensembles), respectively.

Figure 4. January 11, 2006, overflow event. (a) Water temperature in the NB at station 1 (blue line, near surface; red line, near bed) and MB at station 7 (black line, near bed). Near surface-water temperatures are also shown for various stations (symbols given in table 1). (b) Contour plot of downstream water velocity (in $\mathrm{cm} / \mathrm{s}$ ) recorded by the uplooking ADCP at station 7 for an overflow event. The downstream direction is away from the lake (west). Simultaneous mean downstream water-velocity profiles recorded at station 7 by both the uplooking ADCP (squares) and the tethered ADCP (circles) are overlaid. Uplooking ADCP profiles averaged over two periods (from 9:32 to 12:00, left; from 12:00 to 16:00, right). Vertical blue lines show the time limits of the synoptic YSI measurements at station 7 (which encompass the tethered boat velocity profiles).

Figure 5. Water-quality and velocity profiles at stations along the Main Branch, North Branch, and South Branch of the Chicago River during the January 11, 2006 overflow event. Station locations are given in Figure 1, Map A. Velocity is given with the downstream (ds) component taken as positive. The sampling period for the velocity measurements at stations 1, 5 and 6 were $10.05 \mathrm{~min}$ (974 ensembles), $13.26 \mathrm{~min}$ (1251 ensembles), and $11.02 \min$ (1040 ensembles), respectively. 
Figure 6. Transition from an underflow event to an overflow event on January 23-27, 2006.

(a) Stick plot of surface wind observed at O'Hare International Airport (sticks point into the wind, north is to the top). (b) Water temperature in the NB at station 1 (blue line, near surface; red line, near bed) and MB at station 7 (black line, near bed). (c) Contour plot of downstream water velocity (in $\mathrm{cm} / \mathrm{s}$ ) recorded by the uplooking ADCP at station 7 for a transition event. The downstream direction is away from the lake (west). Mean downstream water-velocity profiles recorded at station 7 by the uplooking ADCP (squares) are overlaid. Vertical blue lines show the time limits for each of the averaging periods.

Figure 7. Total chloride concentrations measured in the Chicago River system (left axis) and total lockages at the Chicago Harbor Lock (right axis, grey line, dot markers) for the period 2000 to 2006. Water-quality monitoring station locations are given in Figure 1. Data provided by the MWRDGC and the U.S. Army Corps of Engineers.

Figure 8. The Illinois Environmental Protection Agency's steam water-quality assessment (Illinois Environmental Protection Agency 2004). Water-quality assessment shows the support levels for aquatic life. The yellow areas show the approximate extent of combined sewers served by the Metropolitan Water Reclamation District of Greater Chicago (digitized from an MWRDGC publication). 
Table 1. Sampling stations and instrumentation. ${ }^{1}$ December 19, 2005 event; ${ }^{2}$ January 11, 2006 event. Along-stream distances given are measured distances downstream (DS) from station 1. Profile start times refer to the YSI water-quality measurements. Synoptic velocity profiles were gathered within the sampling period of the YSI measurements.

\begin{tabular}{|c|c|c|c|c|c|c|c|c|}
\hline Station & Name & $\begin{array}{c}\text { Profile } \\
\text { Start } \\
\text { Times } \\
\text { Dec. 19, } \\
2005 \\
\end{array}$ & $\begin{array}{c}\text { Profile } \\
\text { Start } \\
\text { Times } \\
\text { Jan. 11, } \\
2006 \\
\end{array}$ & $\begin{array}{c}\text { Approx. } \\
\text { Distance } \\
\text { DS from } \\
\text { Station } 1 \\
\quad(m)\end{array}$ & $\begin{array}{l}\text { Width } \\
\text { (m) }\end{array}$ & $\begin{array}{l}\text { Sampling } \\
\text { Location }\end{array}$ & Instrumentation & $\begin{array}{l}\text { Figure } \\
\text { Symbol }\end{array}$ \\
\hline 1 & Grand & $13: 15$ & $11: 18$ & 0 & 56 & $\begin{array}{c}\text { Right } \\
\text { Bank }^{1}, \\
\text { Center } \\
\text { Line }^{2} \\
\end{array}$ & $\begin{array}{c}\mathrm{YSI}^{1,2} \\
\text { Tethered } \\
\mathrm{ADCP}^{2}\end{array}$ & 0 \\
\hline 2 & Kinzie & $13: 36$ & 11:42 & 297 & 52 & $\begin{array}{l}\text { Center } \\
\text { line }\end{array}$ & $\begin{array}{c}\text { Tethered } \\
\text { ADCP }^{1,2} \\
\text { YSI }^{1,2},\end{array}$ & + \\
\hline 3 & DS Kinzie & $13: 52$ & 12:04 & 419 & 65 & $\begin{array}{l}\text { Left } \\
\text { Bank } \\
\end{array}$ & $\mathrm{YSI}^{1,2}$ & $x$ \\
\hline 4 & Franklin & N/A & $12: 50$ & 515 & 71 & $\begin{array}{l}\text { Center } \\
\text { line }\end{array}$ & $\begin{array}{c}\text { Tethered } \\
\text { ADCP }^{2}, \mathrm{YSI}^{2} \\
\end{array}$ & $\star$ \\
\hline 5 & Wells & 14:08 & $12: 34$ & 863 & 79 & $\begin{array}{c}\text { Center } \\
\text { line }\end{array}$ & $\begin{array}{c}\text { Tethered } \\
\text { ADCP }^{1,2}, \mathrm{YSI}^{1,2}\end{array}$ & $\triangle$ \\
\hline 6 & State & $14: 50$ & $13: 10$ & 1358 & 84 & $\begin{array}{l}\text { Center } \\
\text { line }\end{array}$ & $\begin{array}{c}\text { Tethered } \\
\text { ADCP }^{1,2}, \text { YSI }^{1,2} \\
\end{array}$ & $\diamond$ \\
\hline 7 & Columbus & $11: 58$ & $10: 15$ & 2006 & 57 & $\begin{array}{l}\text { Center } \\
\text { line }\end{array}$ & $\begin{array}{c}\text { Tethered } \\
\text { ADCP }^{1,2}, \\
\text { YSI }^{1,2}, \\
\text { Uplooking } \\
\text { ADCP }^{1,2} \\
\end{array}$ & $\square$ \\
\hline 8 & $\begin{array}{c}\text { Lake } \\
\text { Michigan } \\
\end{array}$ & $15: 30$ & N/A & 2800 & N/A & Bank & $\mathrm{YSI}^{1}$ & N/A \\
\hline 9 & Washington & N/A & $13: 44$ & 845 & 65 & $\begin{array}{l}\text { Center } \\
\text { line }\end{array}$ & $\begin{array}{c}\text { Tethered } \\
\text { ADCP }^{2}, \mathrm{YSI}^{2}\end{array}$ & * \\
\hline
\end{tabular}


Table 2. Density current parameters characterizing the underflow and overflow events in the Main Branch of the Chicago River. Negative $U$ indicates upstream flow. *Temperature profile was unstably stratified. $\dagger$ Observations and parameters at Station 1 on January 11, 2006 (NB) are for the observed underflow.

\begin{tabular}{|c|c|c|c|c|c|c|c|c|c|}
\hline Station & $\begin{array}{c}\text { Depth } \\
(\mathrm{m})\end{array}$ & $\begin{array}{c}\text { Interface } \\
\text { Depth }(\mathrm{m})\end{array}$ & $\begin{array}{c}H \\
(\mathrm{~m})\end{array}$ & $\begin{array}{c}U \\
(\mathrm{~cm} / \mathrm{s})\end{array}$ & $\begin{array}{c}\text { Excess } \\
\text { Density } \\
(\%)\end{array}$ & $\begin{array}{c}\text { Re } \\
U H / v \\
x 10^{3}\end{array}$ & $\begin{array}{c}R i \\
g^{\prime} H / U^{2}\end{array}$ & $\begin{array}{c}F r \\
U /\left(g^{\prime} H\right)^{0.5}\end{array}$ & $\begin{array}{c}\text { Density } \\
\text { Ratio }\end{array}$ \\
\hline \multicolumn{8}{|c|}{ Aecember 19,2005 Underflow } \\
\hline 5 & 7.33 & 3.5 & 3.11 & -3.15 & 0.046 & 64 & 14.3 & 0.26 & $0.038^{*}$ \\
\hline 6 & 7.33 & 4.2 & 2.14 & -3.05 & 0.060 & 43 & 13.6 & 0.27 & $0.004^{*}$ \\
\hline 7 & 6.74 & 4.5 & 1.57 & -2.94 & 0.046 & 30 & 8.2 & 0.35 & 0.102 \\
\hline \multicolumn{8}{|c|}{ B. January 11,2006 Overflow } \\
\hline $1 \dagger$ & 6.03 & 4.4 & 1.19 & -0.58 & 0.002 & 4.6 & 5.6 & 0.42 & 0.04 \\
\hline 5 & 7.33 & 2.7 & 1.92 & -1.86 & 0.007 & 24 & 3.8 & 0.51 & 3.12 \\
\hline 6 & 7.18 & 1.5 & 0.77 & -1.66 & 0.006 & 8.4 & 1.5 & 0.81 & 0.98 \\
\hline
\end{tabular}




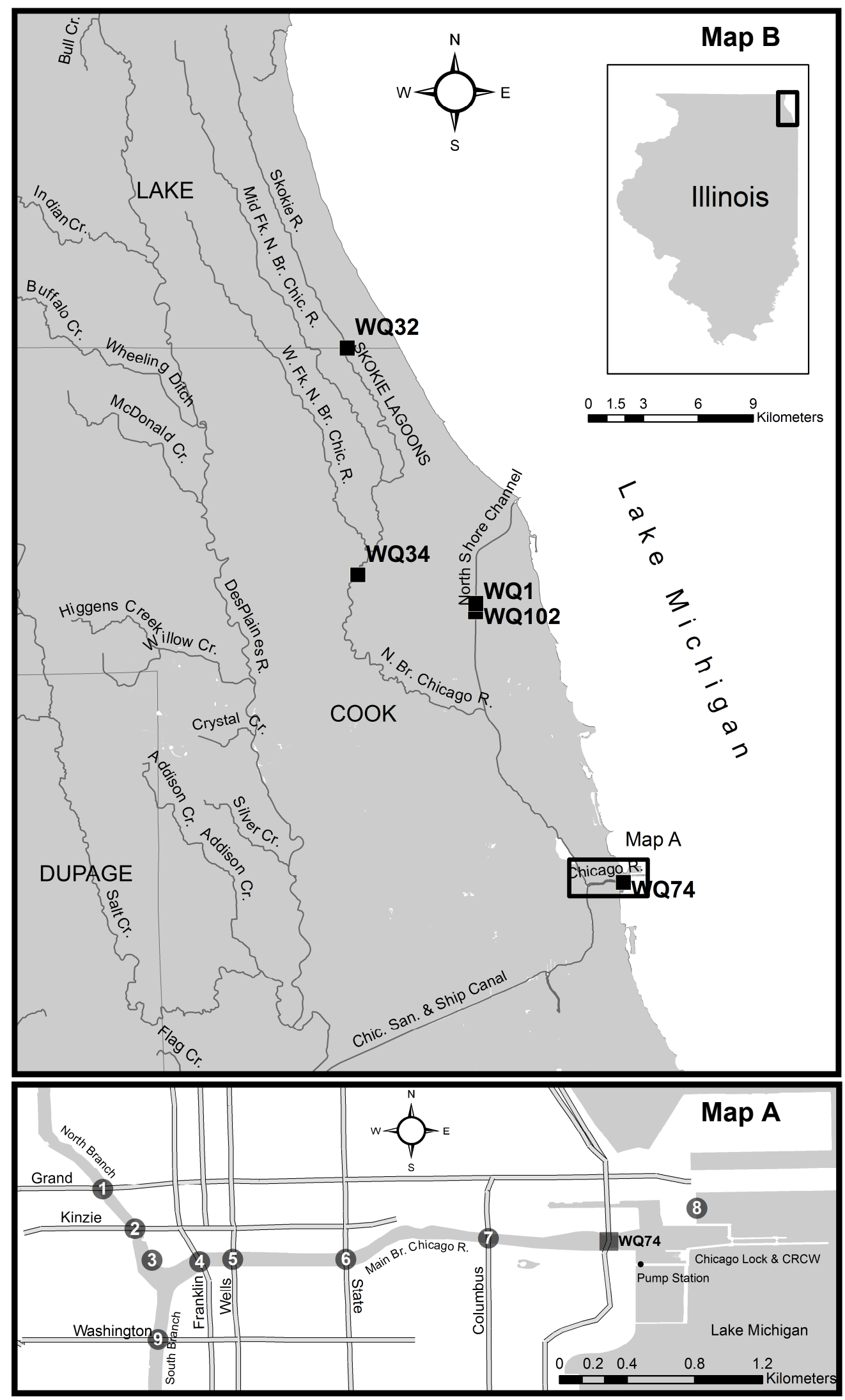

Figure 1 


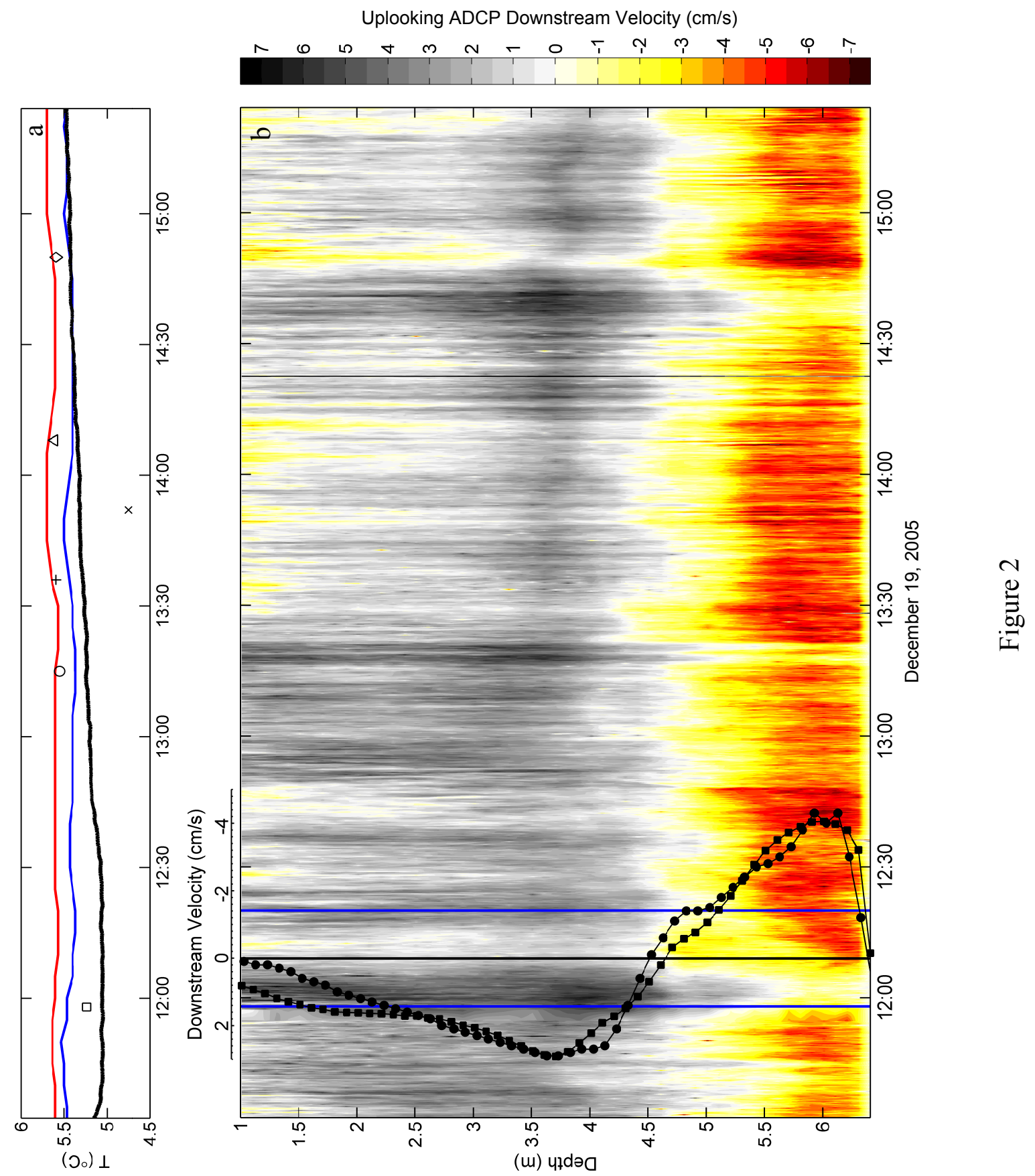



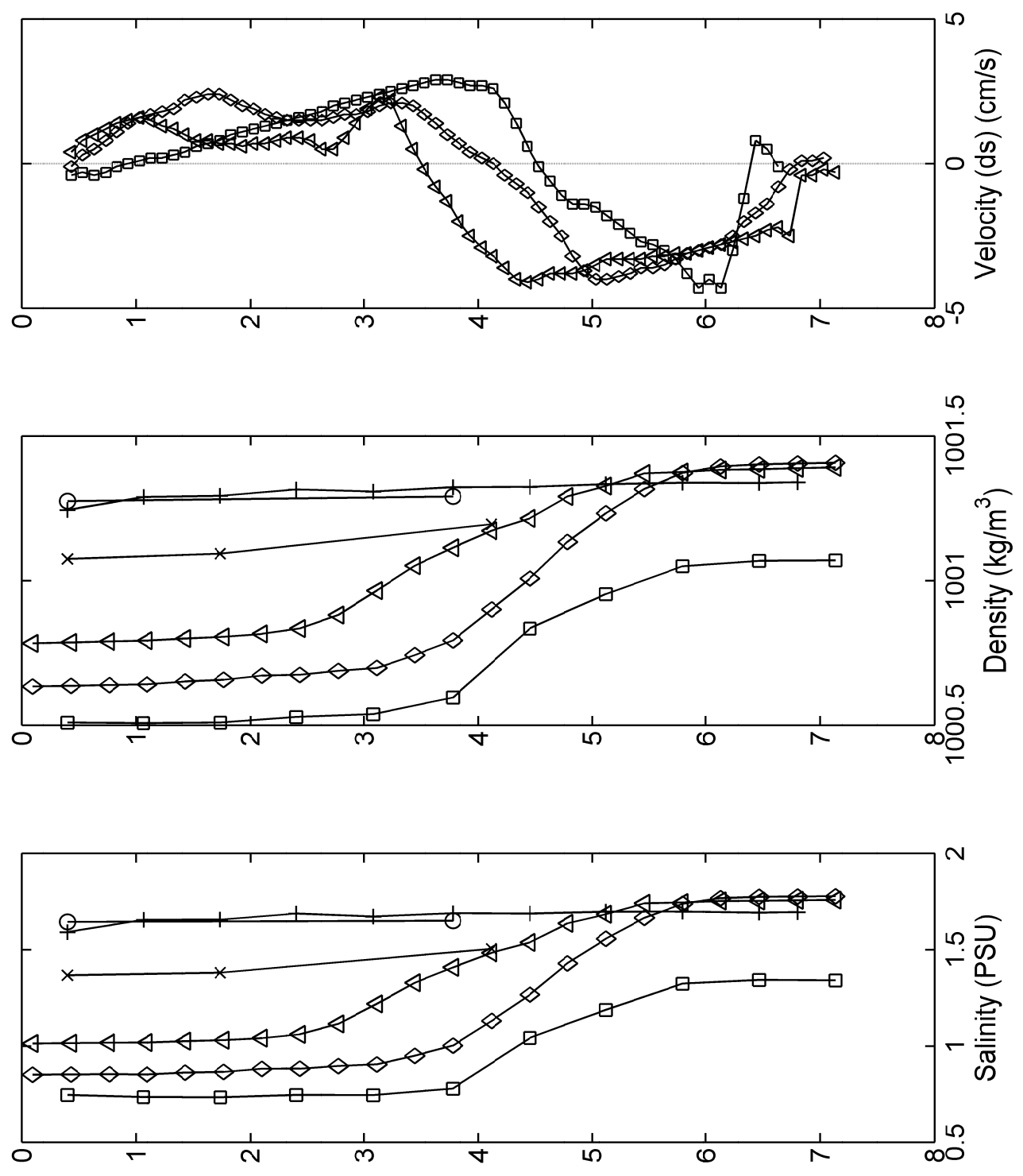

$n$
0
0
0
.00

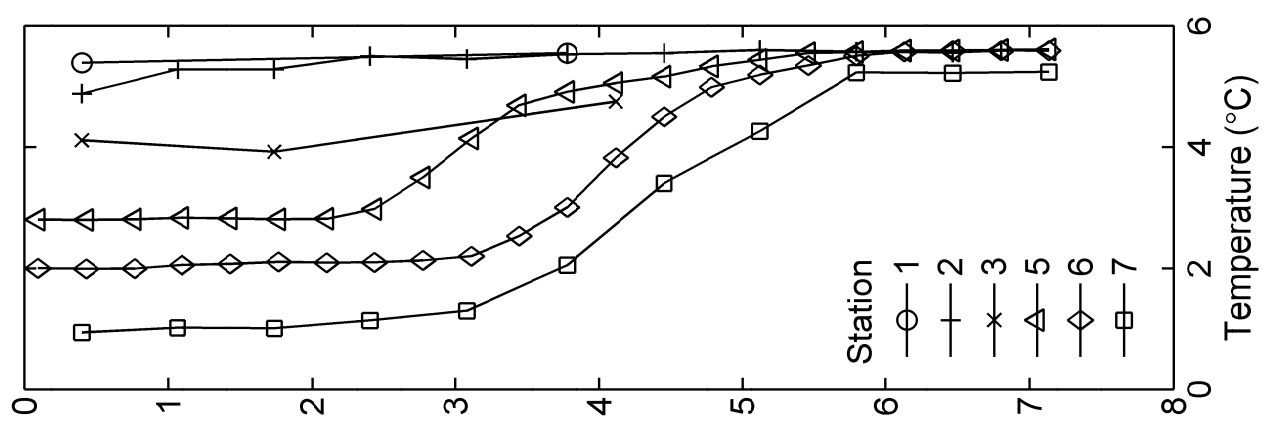

(w) पұd də0 


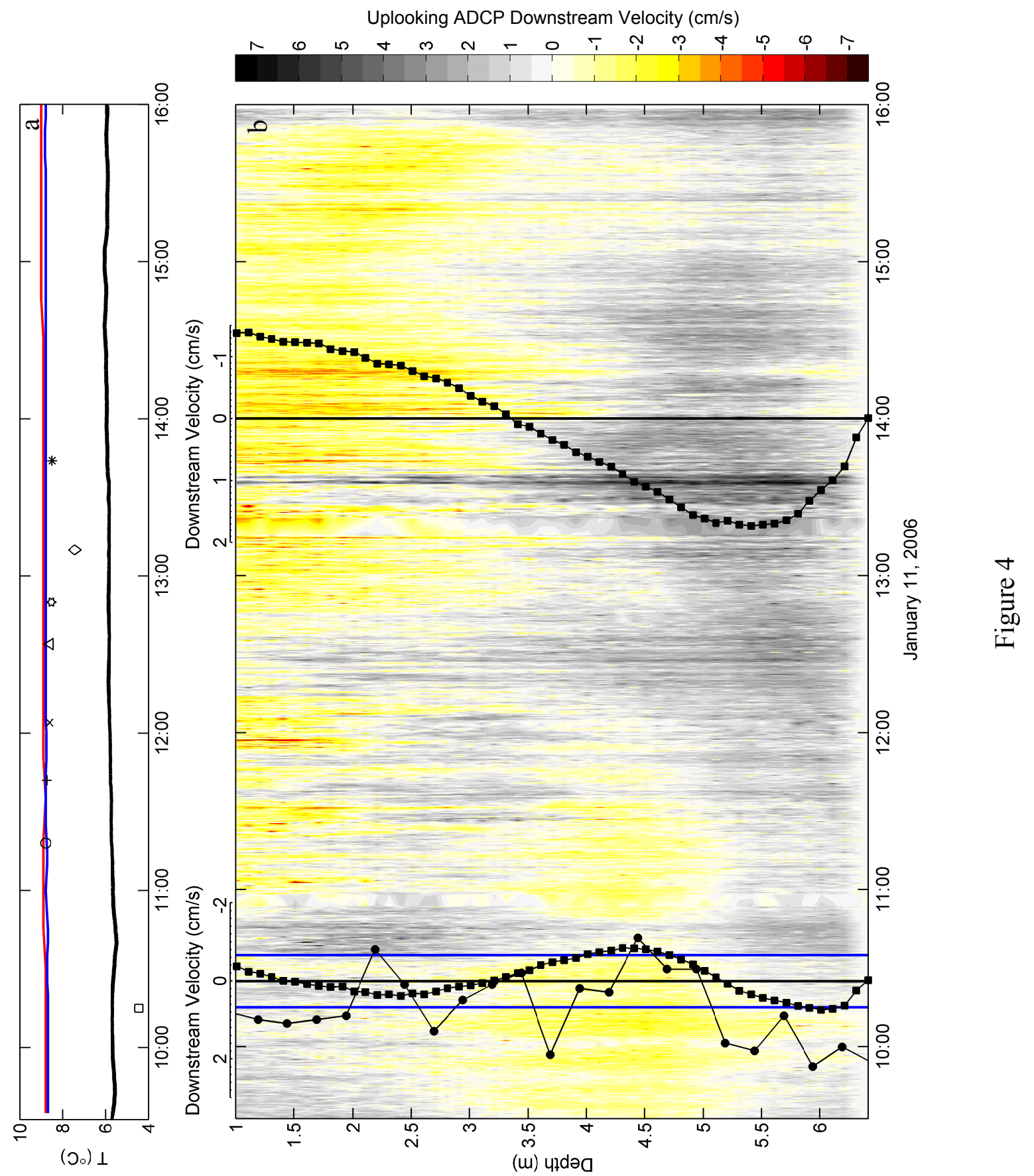



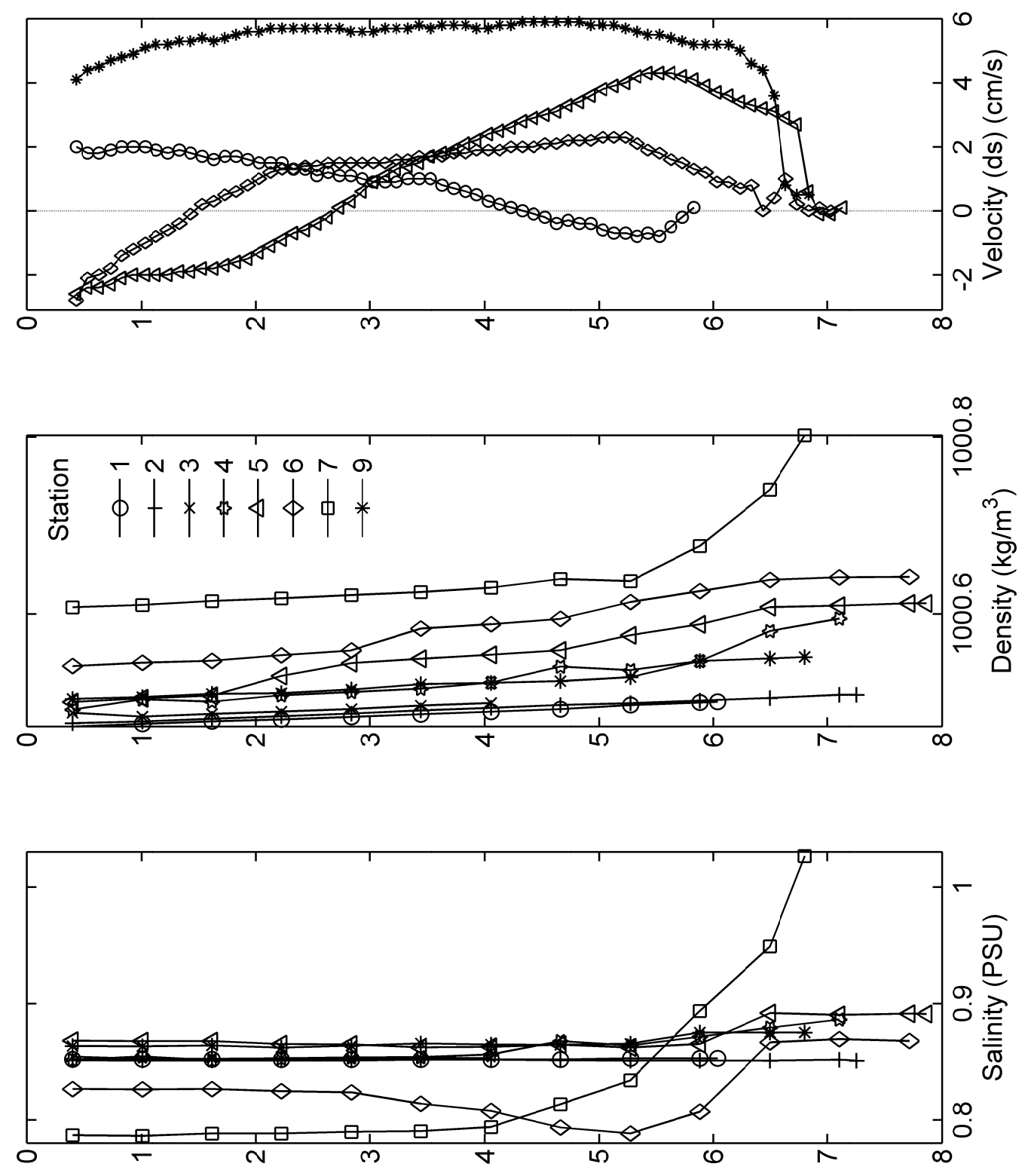

n

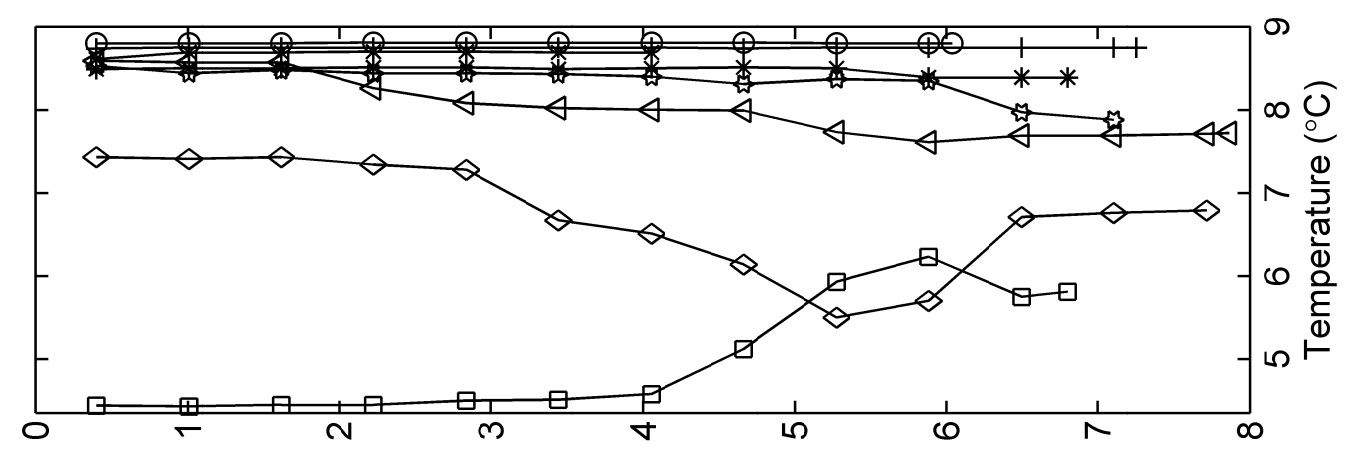

(u) पldə0 

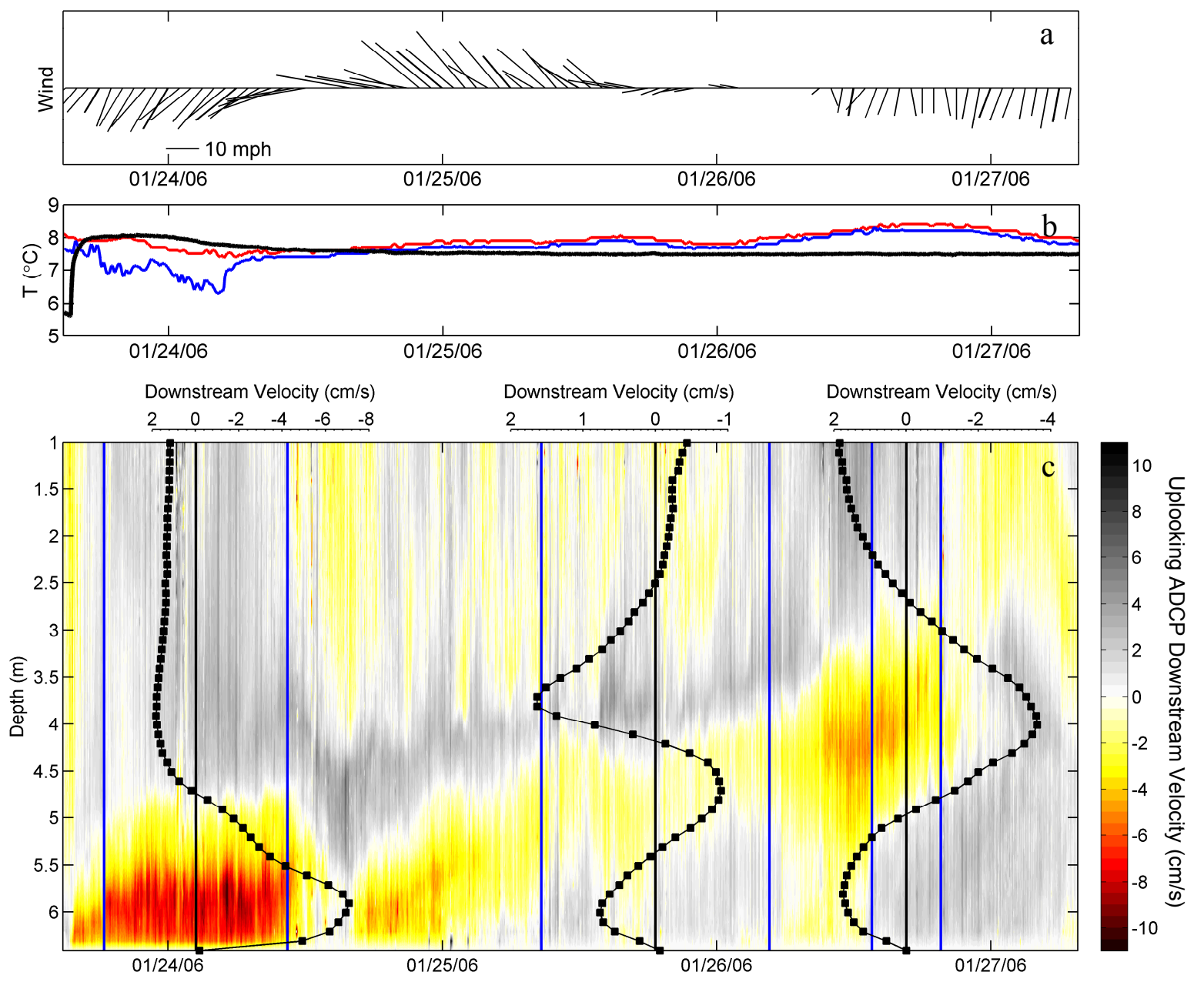

Figure 6 


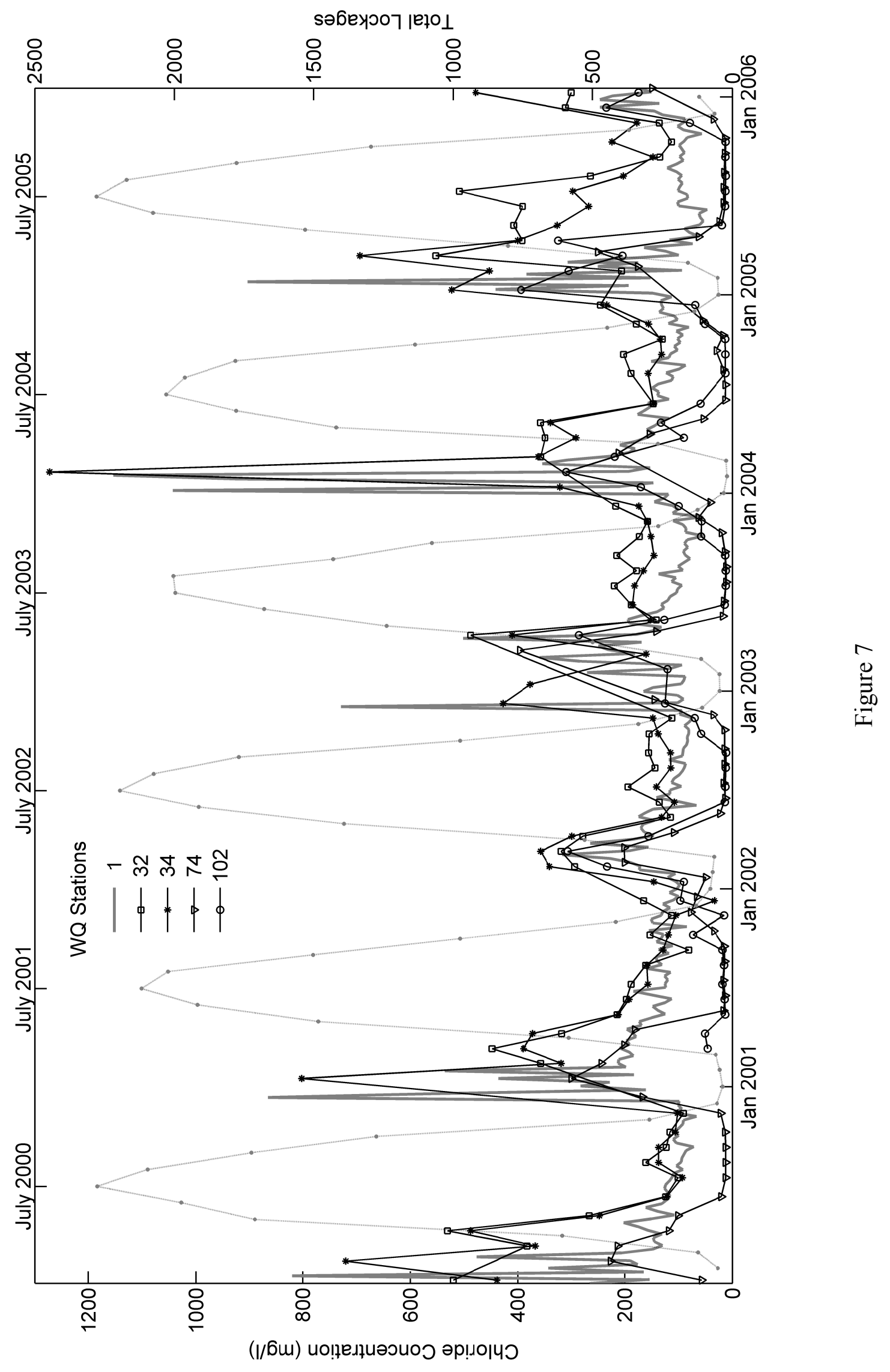




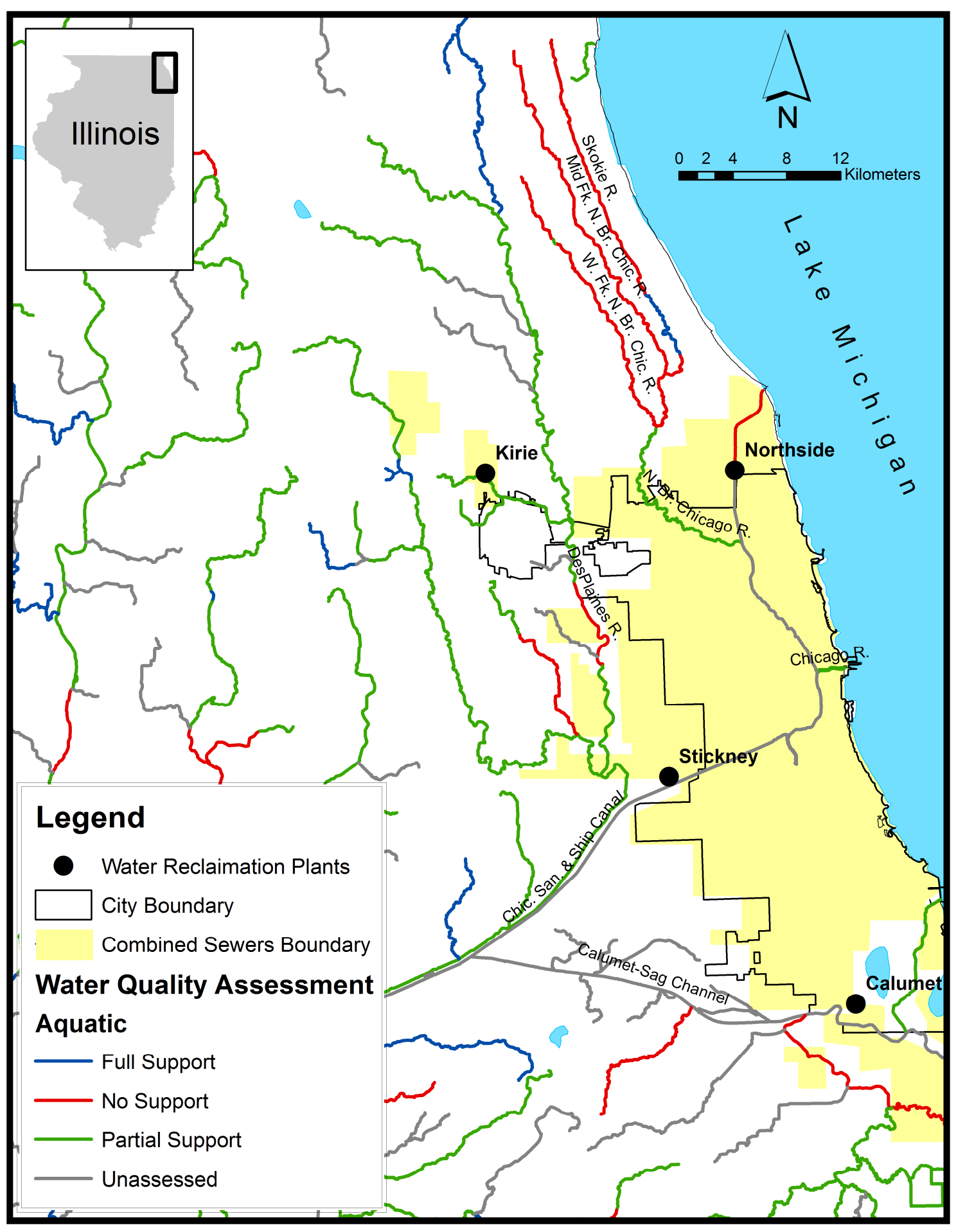

Figure 8 